\title{
Mortgage originations during 2002-2007 as an example of an evolutionary market
}

December 17, 2015

James P. Dow Jr.

\begin{abstract}
The mortgage market in the United States in the early and mid-2000's underwent a substantial shift in both the quality of loans and the nature of the products offered which eventually led to the financial collapse of 2007. However, this change did not happen all at once, instead there was a gradual shift over time as experimenting firms learned that they could sell lower quality loans into the market and other firms were forced to follow along or lose market share. Mortgages started from a position of a stable market with high-quality loans and then shifted over time to a market characterized by continually declining quality and then shifted again sharply back towards high quality, although now requiring government intervention for support. This same pattern was seen across a number of different characteristics of the market. This paper shows how and why the shift happened from an evolutionary perspective and discusses the implications of this kind of behavior for understanding this period and also for possible developments in the future.

Keywords: Subprime; Mortgage; Financial Crisis

G00 Financial Economics

Department of Finance, Financial Planning, and Insurance

California State University, Northridge

Northridge, CA 91330

james.dow@csun.edu, fax: 818-677-6079, phone: 818-677-4539
\end{abstract}




\section{Introduction}

The financial system in the United States, particularly the home mortgage market, underwent a dramatic transformation beginning with the development of mortgage-backed securities and the shadow banking system and ending with the crash and financial panic of 2007 (FCIC, 2011). The period from 2002 to 2007 was particularly notable as the mortgage market changed quickly with an increase in the importance of subprime lending and a rapid decline in loan quality which provides a classic illustration of the importance of evolutionary change.

The basic story of the financial is panic well known. First, there was a long-run shift from traditional banking to shadow banking, particularly in the mortgage market. Low and declining interest rates in the 2000 's along with a stable economy led to an environment of rapidly rising home prices with low-quality mortgages being originated and sold through mortgage-backed securities often repackaged into Collateralized Debt Obligations (CDOs). In 2007, weakening real estate prices and the discovery of the low quality of the mortgages led to a collapse in the mortgage market. Financial markets froze up as banks and other financial institutions that funded their assets with very-short-term money found it hard to refinance their loans and the panic in financial markets spread into the real economy. ${ }^{1}$

This paper focuses on one part of this chain, how the shadow banking market evolved over time in response to innovation by mortgage originators resulting in a rise of non-traditional types of mortgages, particularly subprime loans, and a decline in average loan quality. This process exhibited three classic characteristics of an evolutionary process. First, the market spent a substantial period of time out of equilibrium. At the start of the period, the market would best be described as one where the loans were of generally good quality and this was understood by all participants so the loans could successfully be sold in the market. By 2007 it was discovered that a substantial part of the loans being originated and offered for sale were of higher risk and lower quality than thought and so the demand for them collapsed. However, this shift did not happen all at once, rather the nature of the loans originated and sold over time shifted in response to competition within the market. This behavior was particularly evident in the market for subprime loans, which began small, grew rapidly and then collapsed.

The dynamics of the market were driven by competing firms taking different strategies towards the nature and quality of the mortgage products they offered. Some firms were conservative in their risk management policies and with the mortgages they originated. Other firms simply followed the risk standards set by other firms in the market. However, the securitization of low-quality loans was an underdeveloped niche and a new class of firms arose that were "risk innovators", experimenting with new products and lower standards to see what would sell to consumers and what would be bought in the secondary market. Within the mortgage market, these firms gained market share at the expense of more conservative firms. Some firms responded by following the declining quality standards set by the innovative firms in order to win back business and improve their profitability and market position in the short run. Other firms chose to complete less actively, which reduced their business in the short run but which also improved their survivability in the long run. Heterogeneity of firm behavior is important to

\footnotetext{
${ }^{1}$ See Belsky and Richardson (2010) for rising home prices and the growth of alternative loans and low-quality loans, McLean and Nocera (2011) and Muolo and Padilla (2010) for popular accounts of changes in the mortgage industry, and Gorton and Metrick (2012) and Longstaff (2010) for a discussion of how problems with securitized subprime loans spread into broader financial markets.
} 
understanding this period as theories emphasizing external incentives, such as the role of the Community Reinvestment Act or the moral hazard induced by deposit insurance, run up against the fact that similar firms with similar incentives ended up behaving in different ways. Differences in firm strategies and risk management practices were more important than firm type or regulation.

While it has been argued that one can ignore evolutionary phenomena because the evolutionary process will eliminate non-profit maximizing practices (e.g. Alchien 1950), there is nothing to say that the process will be short or costless. In the end, firms making inappropriate decisions will fail and get weeded out of the economy and so from a long-run perspective, best behavior and best corporate practices should dominate. However, as the recent financial crisis establishes, this is not true at every point in time and the cost of the weeding out process can be great. Without the decline in loan quality it is likely that the "great recession" would have been much milder than it actually was. As a practical matter, understanding how this market behaved out of equilibrium is of great importance.

This paper presents a structure for looking at the recent history of mortgage originations (described in section 2 ) by developing a qualitative evolutionary model that emphasizes the interaction of three types of firms following rule-of-thumb strategies (section 3). The shifts in the market did not happen all at once, but were driven by risk innovators experimenting with a number of incremental changes. Section 4 reviews the evidence on the various ways the mortgage market changed and shows how the same pattern is seen across a number of different mortgage characteristics.

The follower and risk innovator strategies followed by many firms are not well described as long-run profit maximization but rather tended to be the result of interactions between different agents within the firm who had competing interests. Section 5 examines evidence from reports and testimony to illustrate why some firms behaved in the way they did.

The final section argues for the advantages of the evolutionary approach when thinking both about the historical behavior of the mortgage market and its possible behavior in the future. This approach may also provide guidance when thinking about new lending innovations such as peer-to-peer lending.

\section{The rise and fall of the shadow banking system}

\subsection{Overview}

The mortgage market has undergone two significant changes in recent years. First, there was a slow but probably permanent shift in the financing of mortgages away from commercial banks to the shadow banking system where mortgages were originated by retail financial institutions and then sold, predominantly to government-sponsored financial institutions that either held the mortgages or repackaged and resold them (FCIC 2011). This set the stage for the second evolution of the mortgage market starting around 2002 and ending with the crash in 2007. While the name subprime crisis captures the role of subprime mortgages during this time, there were actually a number of separate changes in the market:

- Growth in the number of mortgages securitized. 
- Growth in the number and share of subprime mortgages.

- Growth in the number of mortgages sold in the private-label market rather than through Government Sponsored Entities. ${ }^{2}$

- Decrease in the quality of prime and subprime mortgages along a number of different dimensions, including mortgages with limited information about borrow characteristics, lower quality of borrower characteristics and higher loan-to-value ratios.

- Increase in the importance of non-traditional mortgage types in the private-label market.

From 2007 on, the process reversed rapidly with the virtual elimination of the subprime private-label mortgage market (Sengupta and Noeth 2011), decreases in subprime lending and the decline or elimination of certain types of alternative mortgages. The securitized mortgage market was once successful, it then evolved over a sustained period of time towards an equilibrium that was unsupportable, and as of 2015 , reversed towards its original state. While the market always had the potential to be undermined by the adverse selection problem inherent in securitized mortgages, this was not actually a problem for a substantial period of time. It took the actions of a group of innovative firms to push the market in a different direction.

\subsection{Structure and change in the mortgage market}

In the late 1980's the mortgage system underwent a fundamental change in the United States (Belsky and Richardson 2010). Before that time, mortgages were primarily offered by local banks, particularly thrifts, who held the loans on their balance sheet. The weakness of this approach was that funding of mortgages was dependent on local saving so that some slow-growing regions could find themselves with excess deposits and fast-growing regions with a deficiency. The development of securitization dramatically changed this process. With securitization, a group of mortgages were bundled together and then sold as debt securities to investors. Ideally, this improved the mortgage market by letting regions of the country with a high demand for homes be funded by a larger nationwide pool of funds, which lowered interest rates to homeowners and reduced the cost of financial intermediation by reducing the spread between interest rates to borrowers and lenders. The success of this financial innovation was reflected in the decisive shift away from thrifts and towards securitization from the late 1970 's to the early 1990's. Since funding for mortgages primarily came from investors rather than local commercial banks, it became known as the shadow banking system.

When mortgage securitization was new, potential investors were initially wary of the product even though it would turn out that the quality of the product was high, and so the securities had to be actively marketed to investors (Belsky and Richardson, 2010, provide a short history of this period of the mortgage market while Lewis, 1989, has a popular account of the efforts of Solomon Brothers in selling the product early on).

The securitization process was built on the originate-to-distribute model of retail mortgage banking (Agarwal, Chang and Yavas 2012). Mortgages borrowers would initially receive a loan from one institution (either a bank or a non-bank financial institution) which would then sell it to a second institution. This institution might hold the mortgage or alternatively package it in a mortgage-backed

\footnotetext{
${ }^{2}$ At the start of $2006,60 \%$ of outstanding mortgage debt was traded in mortgage-backed securities with $1 / 3$ of this sold through the private-label market (Keys, Mukherjee, Seru and Vig, 2009).
} 
security. As the mortgage market evolved, there were other innovations that added additional steps in the process, such as the use of mortgage brokers who would be compensated for finding customers and bringing them to the institution originating the loan, and at the other end of the process, mortgage bonds were repackaged into Collateralized Debt Obligations and then split into various "tranches" which differed in their repayment risk. Investors could pick which tranche to buy depending on their tolerance for risk and assessment of changes in the economy and mortgage market.

A major player in this market were the agencies sponsored by the US government, primarily FNMA and FHLMC. $^{3}$ These entities held mortgages in their own portfolios and also securitied mortgages to sell in the market. The mortgages sold were guaranteed by the GSEs in terms of credit risk, although interest rate risk still was held by the buyers. A second way that buyers of these mortgages were protected was that credit ratings agencies would assess the default risk of mortgage-backed securites, although in practice their ratings turned out to be highly inaccurate.

However, the GSE guarantee did not eliminate the risk, it simply shifted it from the buyers to the GSEs, so the GSEs themselves took measures to limit risk. First they placed restrictions on the quality of mortgages they would accept. Generally the GSEs purchased higher quality "prime" mortgages of up to a certain size, where mortgage quality was determined by attributes such as FICO (credit) scores, loanto-value ratios and similar variables. ${ }^{4}$ However, there was also information about the borrower that was observable to the mortgage originator but the not the GSEs (sometimes called soft information, in contrast to hard information which is easily quantifiable) which left the GSEs with a problem of adverse selection as mortgage originators could choose to sell them loans with good hard information and bad soft information. However, Argawal, Chan and Yarvas (2012) found that the mortgage sold to the GSEs during that time were not of worse quality than mortgages kept on the banks' books which they attribute to a reputation effect. Since banks would repeatedly sell mortgages to the GSEs, they would not want to get a reputation for selling bad mortgages and so lose access to this market.

There was a much smaller market for securitization outside the GSEs, called the private-label market. This mostly consisted of good-quality loans that were ineligible for the GSEs because of their size.

Despite the adverse selection problem, the market worked well initially with mostly high-quality loans being originated. However, during 2002-2006 there was a shift towards lower-quality loans with greater risk. This was reflected in a number of different ways including an increase in fradulent information, an increase in the importance of subprime loans and private-label securitization, an increase in the use of non-traditional loan types later during period and an increase in holdings of subprime loans by the GSEs. While it was recognized that many of these loans were lower quality, there was a belief that the higher interest rates offered on these loans were sufficient to make up for the extra risk. However, the buyers

\footnotetext{
${ }^{3}$ Colloquially, these institutions were known as "Fannie Mae" and "Freddy Mac" and together with other smaller institutions were known as Government Sponsored Enteties (GSEs). Fannie and Freddie will be referred to as the GSEs in this paper, leaving aside the smaller institutions.

${ }^{4}$ Fannie and Freddie did move into alternative loans in the latter part of the boom. It was estimated that one out of five loans purchased or insured by them between 2005 and 2007 was Alt-A or subprime (McLean and Nocera 2011, pg 185). Primarily these were subprime rather than Alt-A because of affordable housing goals. At its peak in 2004, they bought around 40\% of these loans, primarily the AAA-rated tranches (FCIC 2011, pg 123-124). While these were supposedly low-risk tranches, it was precisely the wrong time to move into this market as this was the period of the fastest decline in loan quality in the mortgage market and the GSEs suffered substantial losses.
} 
dramatically underestimated the level of risk. Indeed, when the risks became commonly known, many of the loan types disappeared entirely after 2006 as they could not be sold at any interest rate that a borrower would be willing to borrow at. This discovery created a fundamental distrust of the mortgage market by investors.

\subsection{The adverse selection problem in a new market}

The development of securitized mortgage markets was one of the most important financial innovations of the last 50 years. One way to model this financial innovation would be as a one-time change in technology where an old arrangement was succeeded with a cheaper, better alternative; in this case, a shift from traditional mortgage finance to a shadow finance system (Figure 1).

However, securitization and shadow finance introduce a complication into mortgage origination because the entity originating the mortgage is not the same as the entity investing in the mortgage. If mortgages involve differing levels of quality that are not observable to the investor, then the investor must trust that the originator is choosing the desired level of quality. This is an adverse selection problem. In practice there was a variety of ways to reduce loan quality and increase risk (discussed in more detail in Section 4); however, they showed a similar pattern over this time and so it can be useful to abstract from these differences and consider for a moment a generic attribute of loans called credit quality.

A simple model of a securitized mortgage market starts with a bank originating a group of mortgages which it then sells to an investor. The bank can select the quality of the loan, which is only partially observable to the investor. If the originator has the incentive to originate good quality loans, the investor will trust them and will choose to buy the mortgage. If the originator has an incentive to originate bad loans and represent low-quality mortgages as high-quality mortgages, then the investor will distrust the originator and choose not to buy. In an equilibrium outcome, expectations of quality would match actual quality, so that there are two possible equilibria. In the first, the mortgage originators sell good loans and the investors trust the originators so that the expectations of quality match reality (as it did before 2002). In this case, the shadow finance market functions as it is supposed to. Alternatively, if originators sell bad loans and investors know this and so distrust them, the shadow finance market fails to develop or falls apart (as it did in 2007). These options are shown in Figure 2.

While there were several institutions designed to support the good equilibirum (in particular, the GSEs and the ratings agencies) it wasn't true that the existence or non-existence of these institutions determined the nature of the market since the institutions existed both when the market worked and when it didn't.

\section{An evolutionary explanation for the changes in the mortgage market}

\subsection{Competing Strategies}

While the changes in the mortgage market are commonly described as a general lowering of standards, the actual process was somewhat different. There was a great deal of heterogeneity in the strategies 
followed by different firms and how the market played out was a result of the relative fitness of these strategies in the particular environment they were in. It was the competition between firms that drove the dynamics of the market.

Firm behavior in this market during this time can broadly be described by three rule-of-thumb strategies. The first is a "conservative" strategy where firms have strong internal risk management controls and emphasize low-risk lending. The second strategy is a "follower" strategy where firms let the market determine the firm's lending standards and the level of risk. The third strategy isa "risk innovator" approach where a firm experiments with lower-quality and higher-risk products to see which will sell in the market without being concerned about the long-run consequences.

If the market consists predominantly of conservative and follower firms, the outcome will be an equilibrium in which loan quality is high and the adverse selection problem is seemingly solved. This was the situation prior to 2002. However, a market with only conservative and follower firms offers a rich environment for risk innovators. Because buyers' experiences were of quality mortgages and low default rates they were accepting of new mortgages which made it easier for risk innovators to sell their products into the market. Because of the innovative mortgage products they offered, risk innovators had a competitive advantage in this market. Follower firms adopted the new mortgage products and these two categories of firms gained market share at the expense of the conservative firms. However, when conservative lending became too little of the market, buyers eventually discovered the low average quality of loans and the market collapsed, leaving just the remaining conservative firms.

Instead of the one-time changes presented in Figures 1 and 2, a better representation of the shadow banking system for mortgages, and the subprime private-label market in particular, is the dynamic cycle given in Figure 3. We can describe the market as having two attributes, quality (good and bad) and perceptions of quality (trust and distrust), recognizing that this description just represents the average nature of the market - at any point in time there were a variety of firms and both good and bad mortgages were sold. The initial position of the market was good/distrust as the potential buyers had little experience with securitized mortgages. Conservative firms dominated in the market offering conservative products which served to build trust. As time progressed, investors became comfortable with the product and the originate-to-distribute model and securitization eventually displaced much of the traditional mortgage finance and the market was characterized by the equilibrium of good/trust.

But the growth of risk innovative firms gradually undermined the market, and for 2002-2007, perceptions of quality did not match the actual decline in quality, and mortgage market was in the disequilibrium state of bad/trust. Finally, the change in the market was recognized and the financial crisis was precipitated with the rapid shift into the bad/distrust state. ${ }^{5}$ Firms that had the biggest increase in market share due to risk-innovative strategies ended up failing and either going bankrupt or being bought out by larger, more-stable companies that had originated fewer of those kinds of loans. The GSEs, who also took a follower strategy, were rescued by the US Government.

In the end, to save the market, the Federal Reserve had to step in as a de facto trusting investor by agreeing to buy mortgage-backed securities. The private label market and the number of exotic loans

\footnotetext{
${ }^{5}$ While there was an asymmetry in the speed of transition, with a gradual shift from good/trust to bad/trust and a rapid shift from bad/trust to bad/distrust, some individuals did have an earlier understanding of the decline in quality as discussed in Lewis (2010).
} 
reverted back in number to the earlier equilibrium. Risk management across mortgage originators has become much more conservative but the Federal Reserve remains a significant source of funds in the mortgage market and the current situation seems most similar to the good/distrust state and it is unclear how quickly trust will return.

Because of the interaction of firms strategies, each of the two equilibria (good/trust, bad/distrust) act as an attractor when the market is in the opposite equilibrium (see Nelson, 1995, for a description of an equilibrium as an attractor in an evolutionary model). No firm stategy is dominant in all situations. In an environment of good markets, the risk innovator strategy has greater fitness in terms of earnings and so will lead to increased market share to these firms. In bad environments, conservative strategies have greater fitness.

While firms are naturally the unit of selection in this model, and represent the expression of a particular strategy, they are not necessarily the unit of decision making. The strategies discussed here were as much emergent properties resulting from competing individuals within the firm as they were explicit goals (although they sometimes were that too). Different individuals connected to the firms had different attitudes towards risk management. Shareholders might prefer the firm to take fewer risks to maximize the long-term profitability of the company, although it is not clear how well shareholders understood the mechanics of the mortgage market. Individuals who worked with customers to originate mortgages were often rewarded based on the number of mortgages originated and so wanted to have the lowest standards possible. Internal compliance and risk management groups were there to lean in the opposite direction. Managers had to referee between competing interests and were subject to their own reward structure. If the firm as a whole is treated as the decision maker, a firm that targeted market share rather than long-run profitability - a behavior that characterizes a number of institutions in the mortgage origination market - would be seen as a failure of rationality or as satisficing behavior. However, for the individual agents making the decisions, making as much money as possible in the short run and then moving on to the next job after the firm fails may be quite rational. Firms that ended up with a short-run maximization strategy may be exhibiting rational behavior, just in an environment where the principle-agent problem for the ownership of the firm has not been solved.

The heterogeneity in terms of the strategies taken by the firms and the resulting competition between strategies distinguishes this approach from others. While the fact that adverse selection problems can undermine markets is well known, the importance of this problem in the mortgage market varied over time because of the interactions between firms following different strategies. Similarly, the notion that a stable environment can produce excess risk taking is not new (Kindleberger 1978, Minsky 1992), however, this process does not inevitably lead to credit collapses or recessions; the period from World War II to 2000 had a number of financial disruptions, but they were relatively small and the macroeconomic effects were smaller. It was the introduction of a new playing field - the shift from traditionally banking to shadow banking - that changed the underlying structure of the financial system in a way that opened up a new environment where risk innovative firms could prosper and then imbed the risk in larger financial institutions.

\subsection{Incremental changes}

The movement away from the good equilibrium and towards the bad was neither instantaneous nor uniform. The risk innovators discovered gradually over time that they would be able to sell non- 
traditional and lower-quality mortgages into the private-label market. An originator would experiment by lowering standards, seeing if the product would sell, both to homeowners and to those securitizing the loans, and if it did, lower standards again. Notably, much of the innovation was not simply changing the quality of borrowers, rather it focused on offering non-traditional mortgages or modifying the characteristics of existing mortgages. As the pool of low-risk borrowers diminished, the opportunity for sales and better margins increasingly were for higher-risk borrows who needed a different type of loan to access the market.

Overall, the mortgage market during this time had the basic structure of an evolutionary model as described by Dosi and Nelson (1994). ${ }^{6}$ Firms compete by following different rules-of-thumb strategies. Firms whose strategy showed more short-run fitness (profitability) gained market share. The market evolved over time and there was no fixed equilibrium, although there were forces that pushed the market towards the different equilibria. Change happened through incremental changes in loan policies rather than firms recognizing and immediately jumping to a new equilibrium. While most evolutionary models of economic change, particularly models of technological innovation, emphasize the positive role of discovery and learning, there is nothing in evolutionary theory that says adaptions must be positive in a social sense. The only criterion is that behavior that is better adaptive to the agent's local environment in a fitness sense is rewarded. For a certain period of time in the US economy, originating increasingly risky mortgages and selling them into the market was a path to profitability that was not generally understood in 2000.

The next two sections explore two of these characteristics in more detail. Section 4 examines the specific attributes of mortgages and the kinds of incremental changes made in the market. Section 5 looks at examples of firm behavior in the market and why different firms decided to follow the strategies they did.

\section{Changes in mortgage characteristics}

The stylized model of section 3 showed the basic pattern in the mortgage industry, where a low-risk and successful market gradually shifted towards being higher risk and then suddenly fell apart. In practice, mortgages were characterized by a number of separate factors that affected their risk. However, these various factors showed the same pattern over this time, with a shift towards riskier characteristics in the middle of the 2000s that accelerated in 2005 and 2006 before collapsing in 2007. The potential strategies of firms in the market were reflected in the range of mortgages offered and the characteristics of borrowers lent to. This section reviews the different loan attributes and collects evidence for how they how they changed over this time. ${ }^{7}$

Prime mortgages, sometimes called " $\mathrm{A}$ " mortgages, are for borrowers with good credit quality and who are able to provide complete financial information. Conforming mortgages are a subset of prime mortgages, consisting of mortgages that meet the minimum credit requirement of the GSEs and with

\footnotetext{
${ }^{6}$ The model laid out in this section should be considered an "appreciative" model in the sense of Malerba and Orsenigo (2002) and Malerba et al. (1999) in that it involves "presenting causal explanations of observed patterns of economic phenomena put forth by empirical researchers" and not as a mathematical "history-friendly" model. ${ }^{7}$ Most of the studies listed here use proprietary data such as from First American Loan Performance or summary numbers reported from Inside Mortgage Finance.
} 
loan values below the maximum amount allowed. Prime mortgages with loan values above the maximum were called jumbo loans and were sold in the private-label market. A traditional mortgage refers to the most common payment structure (in the United States); usually a fixed rate for a fixed term, commonly 30 years (Belsky and Richardson 2010). Traditional conforming mortgages made up the bulk of the mortgage market at start of the 2000 s and was the base from which the market evolved.

Alternatives to these mortgages include loans to borrowers with greater credit risk, or changes in the terms of the loans, often so that they would be more affordable to the borrower in the short run, but also with an increased risk of future default. Alt-A mortgages were generally designed for credit-worthy borrowers who could not document all the required financial information (Sengupta 2010). Subprime mortgages were loans made to borrowers that posed greater credit risk, and because they were not conforming, they were predominantly sold in the private-label market. ${ }^{8,9}$ The subprime crisis gets its name from the dramatic increase in subprime lending over the period, which went from $8 \%$ of mortgage originations in 2003 to 20\% in 2005 before effectively disappearing in 2008 (FCIC 2011, pg 104; Mayer, Pence and Sherlund 2009).

The increase in the importance of subprime lending was reflected in the growth of the private-label market. In the last part of the boom, the private-label market had grown more than $30 \%$ between 2004 and 2006 (FCIC 2011, pg. 102). At the start of 2006, securitized mortgages made up $60 \%$ of mortgage value outstanding and of that, $1 / 3$ was securitized by the private label market (Keys et. al. 2009). $71 \%$ of this market was subprime or Alt-A. In fact, towards the end of the boom in 2005 and 2006, the privatelabel market was securing more mortgages than the GSEs (FCIC 2011, pg. 102).

By definition, subprime loans reflected greater credit risk on average than prime loans and so the increase in subprime lending produced an increase in the overall credit risk in the market. However, in addition to shifts in volume across mortgage categories, there was also evidence of a decline in borrower quality within categories. It is important to distinguish between so called hard information, which are numbers that are reported to the mortgage buyer by the originator, such as a FICO score or the loan-to-value ratio, and soft information, things the mortgage originator knows but are not reported to the buyer of the loan, for example, personal information inconsistent with reported income. In the loan-to-distribute model, there is an incentive to sell loans with good hard information and bad soft information, since the price would be determined from the hard information. While there is some evidence that originators did not do this with loans sold to the GSEs early on (Argawal, Chan and Yarvas 2012) there is a variety of evidence that this was the case for loans in the private-label market. Some of this evidence is anecdotal such as this description of Countrywide's behavior as "they always put the worst-performing ones into the securities" (Mualo and Padilla 2010, pg 265) but there is also a variety of indirect statistical support. Calen, Henderson and Liles (2007) find that the likelihood of sale of a loan decreased with observable risk but increased with unobservable risk and that buyers didn't understand the difference in composition of loan pools. Anderson, Capozza and Van Order (2011) decompose the risk of default into underwriting standards and changes in the economy and they find that there were two major periods of decline in loan quality. In the middle and late 1990s, and then after 2002, there was a decline in loan performance, although there was little change in observable standards, suggesting a decline in unobservable quality. Demyank and Van Hemert (2011) find that "loan quality, adjusted for

\footnotetext{
${ }^{8}$ There is no official definition or criteria for subprime. Sometimes the term nonprime is used to describe Alt-A and subprime mortgages collectively.

${ }^{9}$ The GSEs did increase their holding of these mortgages later during this period (Argawal, Chan and Yarvas, 2012) .
} 
observed characteristics and macroeconomic conditions, deteriorated monotonically between 2001 and 2007". Using data from LPS Analytics, predominantly from mortgages originated in 2005 and 2006, Elul (2011) finds that private-label securitized loans performed worse than similar non-securitized loans. Interestingly, the effect was strongest for prime loans, likely jumbo loans in this case, while with subprime mortgages, the effect was strongest for loans with reduced documentation (this practice is discussed below). Garardi, Lehnert, Sherlund and Willen (2008) find that subprime loans originated in 2005-2006 had worse observable risk characteristics than loans originated prior to that time but defaulted at a higher rate than they should have given their observable characteristics. As an example of this, they found that the average default rate on loans originated in 2006 exceeded the default rate for the riskiest category of loans originated in 2004. Purnanandam (2011) found that banks that focused on the originate-to-distribute model originated excessively poor quality mortgages as measured by the number of defaults. This difference was not explained by borrower quality, geographic location or cost of capital. In addition, banks that focused on the originate-to-distribute model had significantly higher chargeoffs after the first quarter of 2007 when the subprime market collapsed, as they could not sell the bad loans they had in process and were forced to hold them in their portfolio.

A different approach was taken by Keys et al. $(2010,2012)$ who compare loans made to borrowers with FICO scores on both sides of 620 , which was used as a rule-of-thumb to judge which loans could be easily securitized, with loans at or above this line being much easier. They found that loans slightly above this line defaulted slightly more often than loans with slightly lower FICO score, which is the opposite effect one would expect if loan quality was adequately captured by credit score. They attribute this to adverse selection where bad loans (based on soft information) with good enough FICO scores (just above 620) would be sold while good loans with poorer FICO scores would be kept. This effect was strongest for private-label loans with reduced documentation, presumably since the reliability of the income and asset information is difficult to judge with limited documentation and so soft information would play a greater role. Apparently, reputation as a way of enforcing the "good" equilibrium gradually broke down over this period, with a lowering of borrower quality based on soft information, particularly in the private-label market.

Another way that important information about the borrower was not conveyed to the buyer was to allow the borrower to self-report financial information about themselves without requiring supporting documentation. These loans were known as low doc loans or stated-income loans. For otherwise prime-quality borrowers, these loans were generally categorized as Alt-A; however, these kinds of loans were also used in subprime lending and became increasingly common over this period.

Since income and other financial variables were not checked, it opened the opportunity for either the borrower or employee of the mortgage originator to misrepresent the information, making the loan look better than it was, and indeed, the informal name for stated-income loans was "liar loans" (LaCour-Little and Yang 2013). In the absence of time series on the amount of fraud, much of the information about this practice is anecdotal, although it can be quite revealing. In an interview, Frank San Pedro, Senior VP for Countryside Home Loans (a division of Countrywide Financial) reported that there were around 5,000 internal referrals of possible fraud in 2004 at Countrywide, which increased to over 10,000 referrals in 2005 and then doubled again in 2006 (San Pedro 2010, 10:30). In other words, fraud at that company showed the same rapid rise at the end of the subprime boom as other negative loan characteristics. 
Another factor that affected the risk of default was the amount of equity the borrower had in their house. Typically, borrowers were required to provide some initial equity, for example, the loan might be for no more than $80 \%$ of the price of the home. This gave the owner of the home a cushion, so that even with a fall in house prices, the borrower would not have an incentive to default and walk away from the loan. Borrowers with a smaller down payment were often required to buy private mortgage insurance that would pay in the case of default. And indeed, GSE's would not buy loans without a loanto-value ratio of less than $80 \%$ unless the borrower had private mortgage insurance (FCIC $2011 \mathrm{pg}$ 109). This didn't limit other institutions from either offering these loans for their own portfolio or selling them into the private-label market. This allowed banks to attract borrowers who did not have sufficient assets to make a large down payment.

Another way of getting around the down payment requirement was the use of "piggyback" loans (sometimes known as 80/20 loans). The borrower would come up with the $20 \%$ down payment to get the first loan, but would do so using a second loan so that the total loan-to-value ratio for the house was $100 \%$ rather than $80 \%$, exposing the buyer of the loan to a greater risk of default if housing prices fell. This allowed the originator to sell the first mortgage (which satisfied the $80 \%$ requirement) to the GSE's (FCIC 2011, pg 110). In some cases, the purchaser of the loan did not know about the second loan which was then called a "silent second".

Because homeowners who could not afford a signicant down payment (or any down payment) represented an undersold market, mortgage originators increasing developed products for those customers as a way of generating loans to sell for securitization. The average loan-to-value ratio went from 79\% to 86\% between 2001 and 2006 (Demyank and VanHement 2009). In 2003, 1/5 of subprime and Alt-A loans had piggybacks, in 2006, over half. During the same period, jumbo loans with piggybacks went from 11\% to 33\% (Belsky and Richardson 2010, pg 36). Using a different data set, LaCour-Little, Calhoun and $\mathrm{Yu}$ (2011) estimate the piggyback share for loans originated in 2001 at $9 \%$, increasing to $26 \%$ by 2006 and then dropping to $4 \%$ in 2008 at after the subprime market collapsed. ${ }^{10}$ The changes were even larger at companies that were the most aggressive about subprime lending, for example, from 2003 to 2005, piggybacks went from 9\% to 35\% of New Century's business. (FCIC 2011, pg 110).

Risk can be increased not only by lending to lower quality borrowers but also by structuring the loans in ways that increase the probability that the borrower will be unable to make the payment in the future. While alternatives to the 30-year fixed rate mortgage have existed for some time, with many of the exotic variations going back to the 1980s, they became a much larger part of the market during the subprime boom. In 2003, $66 \%$ of subprime loans were traditional fixed rate, but that dropped to only 26\% in 2006 (Belsky and Richardson 2010, pg 38). The most popular type of adjustable loan during this period was the hybrid adjustable rate loan, either the $\mathbf{2 - 2 8}$ or $\mathbf{3 - 2 7}$, with $\mathbf{7 0} \%$ of subprime borrowers used hybrid ARMs (FCIC 2011, pg. 104). The first two or three years of the loan would be at a fixed rate which would then reset to an adjustable rate for the remainder of the loan. The initial rate was often significantly lower than the expected future rate and sometimes referred to as a "teaser rate". These

\footnotetext{
${ }^{10}$ They also found that the effect of piggybacks on default depended on the nature of the two loans. If both loans were prime, the effect was not significant for owner-occupied properties but it was significant for investment purchases. Presumably investors were more likely to walk away from a negative-equity position than owneroccupiers. However even for owner-occupied purchases, a subprime second was significant in predicting default.
} 
loans were particularly popular for subprime borrowers, the idea being that the initial low rate would give the borrower time to improve their credit and then later refinance to a prime loan, although there were also sometimes restrictions on how soon the borrower could refinance the loan which meant that the borrower could face several years of higher rates. The low initial rate also served to attract borrowers by allowing them to buy a more expensive house for a given level of income but then putting them in a position of facing payment shock when the loan shifted to the adjustable rate period.

An additional risk factor added to an adjustable rate loan was a balloon payment, where in exchange for lower interest rates early on, the balance must be paid off after a certain period of time. Balloon payments followed the same pattern as other risk factors, increasing from around $5 \%$ in 2003 to slightly less than 20\% in 2007 (Belsky and Richardson 2010, table 2-5). The combination of risk factors compounded the risk: Over this period there were more subprime loans; within subprime loans there were more variable rate loans; within variable rate loans, there were more with balloon payments.

Interest-only loans (IO loans) were loans where for a fixed period of time only the interest payment on the loan was made so that there was no accumulation of principle. This allowed the borrower to obtain a larger mortgage for the same mortgage payment but did not result in the borrower building up any equity in the loan. These, along with balloon payment loans, were seen as desirable for those who were going to "flip" a house, that is, buy a house with the intention of soon reselling it to take advantage of risking home prices. However, these loans involved more risk as they assumed that the individual would be able to sell the home for at least as much as they paid or to refinance to a more traditional mortgage.

An important variation on IO loans that offered flexibility for the borrower but increased the risk of default was the pay-option ARM. The pay-option part of the loan indicated that the borrower could choose their monthly payment; this might be an amortizing payment that covered interest and some principle, a payment that covered just interest, or a payment that didn't fully cover interest with the difference being added to the principle, so called "negative amortization". In the latter case, once the principle rose to a certain point, the borrower would then be required to make a fully amortizing payment which would result in a dramatic increase from the minimum payment and subject the borrower to payment shock. This kind of loan allowed the purchase of an even larger house than an IO loan, although with an attendant increase in risk for the lender since there was the possibility of reduction in borrower equity and borrowers who did not even have the income to make the interest payment would likely have a greater risk of default.

IO loans and pay-option ARMs were not an important part or the mortgage market until the last years of the subprime boom when they dramatically increased in number, going from a few percent in the early 2000 s to a peak of about 19\% in 2005 (Belsky and Richardson 2010, pg 40). Pay-option ARMs by themselves went from 2\% of market in 2003 to $9 \%$ in 2006 (FCIC 2011, pg. 105). Several major mortgage companies placed pay-option ARMs at the center of their mortgage strategy. Washington Mutual had offered pay-option ARMs since 1986 but pushed them aggressively in 2003 and 2004, with these loans making up one half of their originations in 2004. Countrywide Financial also aggressively pushed these loans and at their peak in the second quarter of 2005 they made up $25 \%$ of their originations (FClC 2011, pg. 107).

In addition to an increase in the volume of these kinds of loans, their risk characteristics evoloved over time. Golden West Savings (acquired by Wachovia in 2005) was an early adoptor of pay-option ARMs 
and set the standard terms for the reset conditions at 10 years or $135 \%$ of value (FCIC 2011, pg 106). Countrywide Financial and Washington Mutual changed the terms to 5 years or $110 \%$ (making it sooner that the borrower would face reset if the real estate market turned down) and offered teaser rates as low as $1 \%$ (FCIC 2011, pg 107). The credit quality of borrowers with these loans declined over time as companies competed for business. For example, Countrywide repeated lowered standards; in 2004 allowing a combined loan-to-value ratio up to $90 \%$ (from the traditional maximum of $80 \%$ ) and reducing the minimum FICO score to 620 . In 2005, the maximum loan-to-value ratio was increased to $95 \%$ (FCIC 2011, pg 107). Compounding the risk, $68 \%$ of pay-option ARMs were low doc for Countrywide and Washington Mutual in 2005 (FCIC 2011, pg 108).

\section{Three Examples of Strategic Decisions by Mortgage Originators}

\subsection{Innovative firms}

Changes in the mortgage market were pushed by both monoline lenders specializing in subprime mortgages (most significantly Ameriquest and New Century) and several larger banks who aquired and adopted the approaches or products of the smaller institutions they purchased (e.g. Washington Mutual's purchase of Long Beach Mortgage and Wachovia's purchase of Golden West). All four companies became leading mortgage originators. While much of the strategies of these firms was built around maximizing the volume of sales and having weak risk-management controls, there was also innovation in loan types in response to changes in the market. Ameriquest recognized early on that if were to expand its lending to borrowers with bad credit it would have to reduce the income and down payments these borrowers would need (Muolo and Padilla 2010, pg 86). Ameriquest started the use of stated-income and no documentation loans (Muolo and Padilla 2010, pg 87), which circumvented the problem of low income and built its lending around the 2/28 loan, which allowed for low mortgage payments in the first two years (McLean and Nocera 2011, pg 130). The change to non-traditional loans in order to bring in borrowers not qualified for traditional mortgages also affected their attitudes towards fraud. When Ameriquest began to offer $80 / 20$ loans, a loan designed for individuals with little assets, fraud investigation guidelines became laxer at the same time (Lindsay 2010, 15:00). Ameriquest continued to innovate until the very end. In early 2007 , when it became more difficult to sell adjustable rate loans, the company began marketing a 40-year fixed rate loan which would avoid adjustable rates but still offer lower monthly payments than the traditional 30 -year fixed rate loans. (Muolo and Padilla 2010, pg 98).

Since Ameriquest was a trendsetter in terms of loan standards, it forced a difficult decision on other firms who had to consider whether to match them on both quality and price. As a competing executive was quoted as saying, "Every time we rejected a loan, the sales force would call up and say, 'Well, Ameriquest is doing this"' (McLean and Nocera 2011, pg 137). Companies willing to match Ameriquest standards soon found themselves in price wars which cut into their margins. For loans such as the 2/28, price wars were over teaser rates (the rate in the first two years) which lowered the initial payments to borrowers but did little to improve the long-run affordability of the loan. (Muolo and Padilla 2010, pg 169). 
Firms looking to escape the price competition and the associated low margins could respond by offering alternate types of loans. While Washington Mutual was not the first to offer the pay-option ARM, it decided to put it at the center of its lending strategy. This loan had the best margins (Teal 2003, pg 344) and offered more than five times the profit of a prime fixed-rate loan when sold for securitization (McLean and Nocera 2011, pg 135).

The difficulty with selling this kind of loan turned out not to be with institutions buying them for securitization but with convincing consumers to choose them over more standard (and lower-margin) products. In a set of internal documents, Washington Mutual explored ways to increase sales of payoption ARMs. A key factor in the reports was how the complexity and potential risks of the loans bothered consumers: "Option ARMs are very complicated and need to be explained in simple, easy to understand terms. Prospective borrowers need to be educated about the loan - this is not a product that sells itself" (Teal and Baker 2003, pg 333). To successfully sell these loans, they emphasized the importance of consumer-friendly marketing material and targeted particular groups, recognizing that "self-employed individuals and individuals undergoing a significant life change, such as divorce or retirement, may represent an underserved mortgage niche" (Teal and Baker 2003, p 333). In addition, they emphasized the importance of making these loans attractive for the mortgage brokers to recommend them to their customers (Teal 2003, pg ). In the end, Washington Mutual was very successful in promoting the pay-option ARM and it made up half of their originations in 2004 . Other firms had to choose between also offering these loans or losing business to Washington Mutual.

\subsection{Wells Fargo and the decision not to offer pay-option ARMs}

Not all mortgage originators chose to offer the pay-option ARM. Table 1 lists the top 10 mortgage originators and their issuance of pay-option ARMs in 2006, the last full year before the crisis hit, along with other significant issuers of those loans

The firms that were subprime lenders but who came out best from the financial crisis, such as JPMorgan, Wells Fargo and Bank of America, were the ones who avoided pay-option ARMs, although in many cases they originated a significant amount of subprime mortgages. ${ }^{11}$ Pay-option ARMs were both profitable for the originator and represented much of the worst characteristics of the market in 2007. While it was not these loans alone that led to the failure of the institutions, it was a marker of poor decision-making in terms of risk management.

Interviews with Wells Fargo executives, a bank that stayed out of that market, suggest that they knew exactly the short-run/long-run tradeoff of that decision. ${ }^{12}$ CEO John Stumpf indicated that they faced strong competition from Washington Mutual and Countrywide and that in his words "we were willing to lose people and we did lose revenue and we did lose volume because of that" (Stumpf 2010, 13:00). Mark Oman, Senior Executive Vice President, when asked to describe the cost of not offering products, "Well we lost market share, and the market share that we did have was at a fairly low margin... we lost

\footnotetext{
${ }^{11}$ Although their financial strength led them to purchase failed lenders and they ended up inheriting a number of problem loans.

${ }^{12}$ The Financial Crisis Inquiry Committee was set up by the US Congress to investigate the causes of the recent financial crisis. They interviewed a number of people involved with the financial system at that time and made the audio recordings of the interviews available on their webpage.
} 
some sales reps to competing companies because they were doing other types of products than we were willing to do and our sales force on the retail side was largely a commission based sales force, and if it looks greener on the other side, substantially greener, some people are going to make that change" (Oman 2010, 21:00).

He also contrasted Wells Fargo's position with the monoline lenders, financial institutions that specialized in a narrow range of products. Since Wells Fargo offered a variety of mortgage and loan products, they knew that some parts of their business would be doing well and others not well at any point in time and they didn't "push to hard for growth" in contrast to the monoline lenders who are "largely in one industry with one product, the market comes, the market goes, your mentality, how you deal with that is going to be different" (Oman 2010, 20:00)

Both executives emphasized that offering these loans seemed attractive: "There were temptations, but we were successful in resisting those temptations, in hindsight we look very smart, it didn't feel all that good at the time, we had investors saying why aren't you doing these things, we had analysts saying why aren't you doing these things, we were criticized a lot" (Oman 2010, 34:30). This illustrates the underappreciated heterogeneity in the market. It wasn't the mortgage market that was making bad decisions, it was particular firms, and the firms that survived in the long run were those that tended to follow a strategy that did not gain them market share in the short run.

\subsection{Countrywide Financial}

\subsubsection{The Situation at Countrywide}

The smaller monoline subprime non-bank originators such as New Century and Ameriquest were among the most aggressive about lowering standards and pushing the envelope of what could be offered. (FCIC $2011 \mathrm{pg}$ 89). The larger lenders, more typically banks, then had to choose between losing market share or competing in the market by offering similar products. Perhaps the most interesting example of firm behavior was Countrywide Financial who explicitly adopted a strategy that would gradually but inevitably lead them into financial trouble. Since Countrywide was one of the largest mortgage originators and was active across the range of mortgage products, understanding how and why it behaved the way it did is central for understanding the evolution of the market.

While there is not extensive information about the internal decision making for most of the major mortgage originators, Countrywide provides somewhat of an exception since its important role in the financial crisis resulted in more being written about Countrywide than other firms. ${ }^{13}$ In addition, it was the subject of an SEC suit over insider trading with the suit itself providing both numbers and insights into behavior. ${ }^{14}$

\footnotetext{
${ }^{13}$ This section is drawn from investigative reporters and popular accounts (McLean and Nocera, 2011; Muolo and Padilla 2010) along with interviews of several former employees of the firm done by the Financial Crisis Inquiry Commission.

${ }^{14}$ The Securities and Exchange Commission sued former Countrywide executives Angelo Mozilo (CFO), David Sambol (COO) and Eric Sieracki (CFO) in 2009 for making fraudulent disclosures and insider trading (SEC 2009). The suit was settled by with Mozilo paying a $\$ 22.5$ million penalty (SEC, 2010). While the issue of insider trading is
} 
The behavior at Countrywide was characterized by two key features. First, the company had an explicit focus on market share. While this may have not been rational in the sense of maximizing long-run shareholder wealth, it partially reflected rational behavior by individual agents in the firm who were rewarded for generating business and who then could walk away from the firm if things turned bad. Second, the focus on market share was made operational by what was called the "supermarket" or "matching" strategy. Basically, Countrywide chose not to be an innovator in terms of products but made an explicit commitment to match whatever products were successfully sold by competitors. As the more aggressive firms increasingly pushed the envelope of what could be sold, Countrywide followed along.

Most of the loans Countrywide originated during this period were pooled and sold on the secondary market, both to the GSE's and in the private-label market, although it did keep some loans on its own books (SEC 2009, pg. 7). Countrywide had a declared goal of being the largest mortgage originator, but to do this, it had to shift away from its traditional business of underwriting prime conventional conforming mortgages to mortgages with higher risk (SEC 2009, pg. 8).

This section shows how the internal decision making structure of the firm reflected competition among various interest groups and how the matching strategy played out with two particularly risky kinds of loans: pay-option ARMs and 80/20 loans.

\subsubsection{Internal Decision Making}

The choice of the type of loans to offer and lending standards was a result of competition and negotiation between different factions within the company. The product divisions were rewarded for the number of loans they originated and so were the strongest advocate for the matching strategy. The risk management and fraud management divisions were designed to lean the other way and advocate for higher standards. At Countrywide, this led to an adversarial relationship between the groups. There were reports that fraud investigators would have to get permission from sales to visit a branch and in at least in one instance was banned from visiting a branch (Foster 2010, 26:30). The organizational structure at Countrywide compounded this problem as there were multiple divisions, each with its own fraud management group, which undermined their power. In the words of the head of the overall fraud risk management group "fraud units within the divisions were being managed by the sales and production personnel" (Foster 2010, 14:35) to the point where a salesperson could override a fraud investigator on a loan if fraud was discovered (Foster 2010, 20:30). Risk management also was aware of the risks involved and warned that the increased use of alternative loans increased Countrywide's credit risk (SEC 2009, pg. 14); however, the culture was to produce as many loans as possible with due diligence a secondary concern (Muolo and Padilla 2010, pg. 124)

It was the responsibility of upper management to adjudicate between the various competing groups, although in the case of Countrywide, there was not agreement among the senior managers of the appropriate approach to take. The primary executives over this period were Angelo Mozilo (CEO in

not especially relevant for this paper, the complaint includes insider emails that provides information on the internal working of Countrywide. 
2006), Stanford Kurland (President and COO leading up to 2006), David Sambol (in charge of the mortgage banking segment from 2000 and replacing Stanford Kurland as President and COO in 2006) and John McMurry (Chief Risk Officer). While Kurland presided over the increased importance of subprime early during this period, Sambol was more aggressive about expanding into subprime and later in this period replaced Kurland, which pushed the firm in a riskier direction (Muolo and Padilla 2010, pg 124). Mozilo was inconsistent, promoting non-traditional and high risk loans in public, while expressing concerns in internal emails, although not directly taking action to prevent them. Countrywide's strategy was not an inevitable result of the market (indeed, other companies managed to not follow it); if Kurland was not succeeded by Sambol, or Mozilo had taken a stronger stand, or McMurry had been given more influence, the story for Countrywide would likely have been different. There was nothing inevitable about Countrywide's movement into the subprime market, although given the opportunities to sell low-quality loans and profit, it was likely that some firm would have been pulled in.

\subsubsection{The "matching strategy"}

In several public statements, Mozilo indicated the importance to the company being a market leader (for example, he promised investors that he would increase the company's market share from $10 \%$ to $30 \%$ by 2006 or 2007, McLean and Nocera 2011, pg 138). However, this was not done by jumping immediately to the 2006 equilibrium of low standards and non-traditional loans, instead the company followed a policy of watching to see what worked in the market and then offering similar products or standards and then used their large sales force to grab market share. This resulted in the company continually altering its lending standards to include riskier borrowers and emphasize riskier products, as was described in the SEC complaint (SEC 2009, pg. 11):

24. By the end of 2006, Countrywide's underwriting guidelines were wider and more aggressive than they had ever been. The company's aggressive guideline expansion was deliberate, and began as early as 2003. Indeed, from January 2003 until well into 2006, Countrywide's credit risk management department ("Risk Management") spent approximately $90 \%$ of its time processing requests for expansions of Countrywide's underwriting guidelines.

25. Countrywide's "matching strategy," also known as the "supermarket strategy," was a key driver of the company's aggressive expansion of underwriting guidelines. The strategy committed the company to offering any product and/or underwriting guideline available from at least one "competitor," which included subprime lenders...For example, if Countrywide's minimum FICO score for a product was 600 , but a competitor's minimum score was 560 , the production division invoked the matching strategy to reduce the minimum required FICO score at Countrywide to 560 .

The shift in Countrywide's business can be seen along a number of different dimensions. Prime conforming loans (that is, conservative traditional loans) went from $50 \%$ of their originations in 2001 to 31.9\% in 2006 (SEC 2009, pg. 8). Prime non-conforming loan originations (supposedly high quality loans that did not meet the requirements to be sold to the GSEs) went from $16.5 \%$ to $45.2 \%$ (SEC, 2009, pg. 8). This underestimated the magnitude of the shift in product offerings as the prime non-conforming loans included products with increased credit risk; prime loans included borrowers with FICO scores as low as 500 (SEC 2009, pg. 41) when 620-660 was typical for the industry as general (SEC 2009, pg. 9). The loans also included various features that increased risk such as reduced documentation, stated income and 
loan-to-value ratios of 95\% or higher (SEC 2009, pg. 10). The matching strategy was successful in keeping Countrywide's position as a leader in the market - for example, it was the leader in two of the six major subprime categories in 2004 and four in 2005 (SEC 2009, pg. 16). This process continued right up to the time of the crisis. In late 2006, Countrywide approved an expansion of its underwriting guidelines to include what they referred to as "Extreme Alt-A" to match produces offered by Bear Stearns and Lehman Brothers (SEC 2009, pg. 17), both investment banks that would fail during the crisis.

One can see the both the decline in standards and the internal conflicts and ambivalences in Countrywide's promotion of two particularly dangerous types of loans: 80/20 loans and pay-option ARMs

\subsubsection{0/20 Loans}

As discussed in section 4, 80/20 loans consist of two parts, the first loan which has an $80 \%$ loan-to-value ratio and thus satisfies traditional guidelines for mortgage lending and a second loan for the remaining $20 \%$, which replaces the down payment so that the owner has no equity in the home. Any decline in home prices will result in negative equity for the homeowner which makes it easy for them to walk away from the loan, particularly since these loans were targeted towards borrowers who had few assets in the first place. Countrywide was conflicted about these loans; or more accurately, there were individuals within the company that had different attitudes. Mozilo's internal stance was that 80/20 loans were "the most dangerous product in existence and there can be nothing more toxic and therefore requires that no deviations from guidelines be permitted irrespective of the circumstances" and that those loans "could only be originated if Countrywide could totally extinguish the credit risks" (SEC 2009, pg. 20). Despite Mozilo's official stance, internal guidelines were being developed that would have "permitted $100 \%$ financing, layered with additional credit risk factors such as stated income, lower than average FICO scores, or non-owner occupied investment properties" (SEC 2009, pg. 18).

The risk management division could have served as a break on the decline in loan quality; however, they could be circumvented and products were offered by the loan production divisions even if they were not formally approved (SEC 2009, pg. 18). While Mozilo did not intervene, he was aware of the both the failure of the risk management, sending out an email in 2006 that expressed concerns that the loans were originated "through our channels with disregard for process [and] compliance with guidelines" and his dislike of the high-risk products being sold, stating that "[i]n my conversations with Sambol he calls the $100 \%$ sub prime seconds as the 'milk' of the business. Frankly, I consider that product line to be the poison of ours." (SEC 2009, pg. 21)

In the end, Mozilo's warnings were ignored, or not taken seriously, and 80/20 loans became an increasingly important part of Countrywide's business to the point where in the second quarter of 2006, $62 \%$ of subprime originations had a loan-to-value ratio of $100 \%$ (SEC 2009, pg. 22).

\subsubsection{Pay-Option ARMs at Countrywide}

Countrywide began originating pay-option ARM loans in 2004 (SEC 2009, pg. 24). These loans quickly became a large part of Countrywide's business; in 2005 and 2006, pay-option ARMs made up between $17 \%$ and $21 \%$ of Countrywide's total loan originations (SEC 2009, pg. 10). These loans offer additional risks for the lender since individuals who make the minimum payment are increasing their loan principle and may not be able to make the monthly payments when these loans automatically reset, and indeed 
for Countrywide, 71\% made the minimum payment in 2006 (SEC 2009, pg. 27). Compounding this problem was that $80 \%$ of pay-option loans were based on reduced documentation, although this was not disclosed to the market until 2007 (SEC 2009, pg. 41).

Interestingly, most of the pay-option ARM loans were held by Countrywide rather than sold to the market, leaving Countrywide with the risk (SEC 2009, pg. 24). Again, senior management expressed conflicting attitudes towards these loans. In May 2006, Mozilo said publicly "Pay-Option loans represent the best whole loan type available for portfolio investment from an overall risk and return perspective" (SEC 2009, pg. 25), but then in June of that year, he expressed concern internally "that the majority of the pay-option ARM loans were originated based upon stated income, and that there was evidence of borrowers misrepresenting their income" (SEC 2009, pg. 27). Concerns from some parts of the company about the level of risk combined with the sense that these loans were overpriced in the market led Mozilo to believe that these loans should be sold off (SEC 2009, pg. 29), however, this was never done. From the SEC report (pg. 30):

Despite the repeated warnings of Mozilo, McMurray, and the CIO, the Pay-Option ARMs were never sold, and the clearly identified risk to Countrywide were not disclosed to investors. Mozilo recognized as early as August 2006 that Pay-Option ARM loans were one of the "only products left with margins [profit]

In the case of both $80 / 20$ loans and pay-option ARMs there was the same pattern, recognition of the risks of these loans, conflict among agents within the firm about the appropriate action to take, and a final decision to offer these loans in response to desire for market share.

The decline in real estate values and the crash in the subprime market in the second half of 2007 resulted in funding for Countrywide drying up. In addition, Countrywide's earnings were hurt by the poor performance loans on its books, including the high-risk pay-option ARMs along with nonconforming and subprime loans where Countrywide retained residual interests (SEC 2009, pg 14-15), resulting in the company's acquisition by Bank of America (Mildenberg 2008).

\section{Why the evolutionary approach matters for understanding the mortgage market}

The lesson of mortgage crisis, from Countrywide and in general, is not there were mistakes and fraud; firms often make incorrect business decisions and rogue employees or misguided senior management can cause firms to behave in ways that lead to their collapse. What's important is that the mistakes were made in a predictable direction and in response to short-run competitive pressures. Short-run revenue was based on the number of mortgages originated regardless of standard so the incentive was to lower standards to increase market share.

Internal controls to prevent fraud or manage risk broke down in predictable ways. In the battle between origination and compliance, origination generates revenue and compliance does not, making it a matter of "willpower" for a company to resist the lure of low-quality loans. From the experience of 2002-2007, it appears companies differ on the amount of willpower they have and some do develop the right corporate culture or insert suitable controls to prevent this from happening. Unfortunately, even if 
all the existing companies have the willpower to stay out of a new, risky market, it leaves an evolutionary niche for other companies whose primary attribute is precisely that lack of willpower.

Recognizing the heterogeneity of firm strategies is important for evaluating the various popular explanations for why the mortgage crisis happened. Theories that emphasize common factors such as the role of the CRA (Community Reinvestment Act, a regulation requiring banks to offer loans to underserved communities) or the moral hazard due to the government's protection of the banking system run up against the fact that institutions that were equally subject to these requirements managed to avoid the worst excesses in mortgages. In addition, mortgage originators who weren't subject to the CRA sold substantial numbers of high-risk mortgages and the unguaranteed mortgages offered through the private-label market were some of the lowest-quality loans.

The mortgage market in the US was not strongly regulated, although there was substantial government involvement, either directly, or indirectly through the GSEs. However, differences in how regulated the various categories of institutions were do not seem to be important. Keys et al. (2009), using data on subprime mortgages, measured whether banks or non-bank mortgage originators (who were regulated more lightly) originated similar levels of defaulted loans. Surprisingly, the banks had a somewhat worse record, even though they were more tightly regulated in principle. While this is evidence that the regulations were not effective, it has to be placed in the context that some banks managed to avoid the worst of the subprime crisis despite the ineffective regulations. Understanding why financial institutions differ in their abilities to manage risk is at least as important as understanding the failures and successes of regulation. Interestingly, Keys et al. (2009) also find that banks that paid their chief risk manager relatively more tended to produce higher quality mortgages, suggesting the importance of corporate culture in these decisions.

Another feature of the US mortgage market was that much of the innovation wasn't simply a lowering of the required credit scores, which in principle could be easy to monitor, but was rather innovative lenders continually offered new features which made the loans more attractive to consumers but at the same time increased the risks. This puts regulators in the position of having to monitor the qualitative features of different loans to understand the risks being produced by the market and might require regulations to restrict, or allow the states to restrict, the types of loans offered, returning mortgage regulation to the situations before 1982 (Belsky and Richardson 2010, pg 12).

Differences in behavior across banks also have implications for the way regulations should be designed. Regulations structured as incentives, such as taxes on high-risk assets, rely on bank management that is rational and forward looking. However, if there is a market that rewards short-run behavior, there is likely enough variation in bank management that some institution will end up taking excessive risk. Regulations need to be robust to irrational management. Furthermore, it is not sufficient for regulators to establish best risk-management policies at all existing firms. A healthy and stable market will be an attractive environment for new firms with poor risk-management policies. Regulators can look to early adopters of new practices as indicators of where the market might be headed. This was not the first time that the market for low-quality loans rose and fell, there was a smaller subprime boom in the mid to late 90s that was stalled by the Russian debt crisis in 1998 (McLean and Nocera 2011, pg. 32-35; Muolo and Padilla 2010, pg. 158).

A recent innovation in credit markets that bears an interesting resemblance to the shift to shadow banking in the mortgage market is the development of peer-to-peer lending. Peer-to-peer lending 
consists of an individual who lends directly to a borrower, where the loan is coordinated, but not held, through an online platform, such as that offered by Lending Club and Prosper (Cortese 2014, The Economist 2015). The characteristics of this market have certain similarities with the shift to shadow banking in the mortgage market. It is promoted as a way to increase the availability of credit to individuals by making available a new source of funds. The lenders have to rely on basic reports of the credit applicant without meeting the applicant, and to the extent that entities making the loans are individuals, they may not be in a good position to evaluate the credit risks. Finally, the financial intermediaries get their earnings from fees based on the number of loans originated. Right now, this market is still in the development stage and it is unclear what a more mature market will look like. But the lessons from the innovations in the mortgage market are strong. If this market becomes successful and stable, it will be due to the great majority of firms in the market having effective risk-management policies that ensure credit quality. However, when that happens, it creates a desirable environment for firms whose market advantage is not have those risk-management controls. 


\section{Compliance with Ethical Standards}

Conflict of Interest: The author declares that he has no conflict of interest. 


\section{References}

Agarwal S, Chang Y, Yavas A (2012) Adverse selection in mortgage securitization. Journal of Financial Economics 105:640-660

Alchian A (1950) Uncertainty, evolution and economic theory. The Journal of Political Economy 58:211221

Anderson C, Capozza D, Van Order R (2011) Deconstructing a mortgage meltdown: A methodology for decomposing underwriting quality. Journal of Money, Credit and Banking 43:609-631

Belsky E, Richardson N (2010) Understanding the Boom and Bust in Nonprime Mortgage Lending. Joint Center for Housing Studies of Harvard University

Bhardwaj G, Sengupta R (2012) Subprime mortgage design. Journal of Banking and Finance 36:15031519

Calem P, Henderson C, Liles J. (2011) 'Cherry picking' in subprime mortgage securitizations: Which subprime mortgage loans were sold by depository institutions prior to the crisis of 2007. Journal of Housing Economics 20:120-140

Colemen M, LaCour-Little M, Vandell K (2008) Subprime lending and the housing bubble: Tail wags dog? Journal of Housing Economics 17:272-290

Cortese, A (2014, May 4) Loans that Avoid Banks. Maybe not. New York Times, BU1

Demyank, Y, Van Hemert O (2011) Understanding the subprime mortgage crisis. The Review of Financial Studies 24:1848-1880

Dosi G, Nelson R (1994) An introduction to evolutionary theories in economics. Journal of Evolutionary Economics 4:153-172

Elul R (2011) Securitization and mortgage default. Federal Reserve Bank of Philadelphia working paper.

Financial Crisis Inquiry Commission (2011) The Financial Crisis Inquiry Report. Perseus Books Group, Philadelphia

Foster E (2010) fcic.law.stanford.edu/resource/interviews. Accessed 14 July 2014

Frame W (2008) The 2008 Federal intervention to stabilize Fannie Mae and Freddie Mac. Journal of Applied Finance 18:124-136

Gerardi K, Lehnert A, Sherlund S, Willen P (2008) Making sense of the subprime crisis. Brookings Papers on Economic Activity Fall:69-159

Gorton G, Metrick A (2012) Securitized banking and the run on repo. Journal of Financial Economics 104: 425-451

Inside Mortgage Finance (2008) The 2008 Mortgage Market Statistical Annual

Kemp M (2010) Fcic.law.stanford.edu/resource/interviews. Accessed 14 July 2014

Keys B, Seru A, Vig V (2012) Lender screening and the role of securitization: Evidence from prime and subprime mortgage markets. The Review of Financial Studies 25:2071-2108

Keys B, Mukherjee T, Seru A Vig V (2010) Did securitization lead to lax screening? Evidence from subprime loans. The Quarterly Journal of Economics 125:307-362

Keys B, Mukherjee T, Seru A Vig V (2009) Financial regulation and securitization: Evidence from subprime loans. Journal of Monetary Economics 56: 700-720

Kindleberger, C (1978) Manias, Panics and Crashes. Basic Books, New York

LaCour-Little M, Yang J (2013) Taking the lie out of liar loans: The effect of reduced documentation on the performance and pricing of Alt-A and subprime mortgages. Journal of Real Estate Research 35:507-553

LaCour-Little M, Calhoun C, Yu W (2011) What role did piggyback lending play in the housing bubble and mortgage collapse? Journal of Housing Economics 20:81-100 
Lewis M (2010) The Big Short: Inside the doomsday machine. W.W.Norton \& Company, Inc., New York Lewis M (1989) Liar's Poker. W.W.Norton \& Company, Inc., New York

Lindsey P (2010) Fcic.law.stanford.edu/resource/interviews. Accessed 11 December 2015

Longstaff $F(2010)$ The subprime credit crisis and contagion in financial markets. Journal of Financial Economics 97:436-450

Malerba $F$ (2006) Innovation and the evolution of industries. Journal of Evolutionary Economics 16: 3-23

Malerba F, Nelson R, Orsenigo L, Winter S (1999) 'History-friendly' models of industry evolution: The computer industry, industrial and corporate change 8:3-40

Malerba F, Orsenigo L (2002) Innovation and market structure in the dynamics of the pharmaceutical industry and biotechnology: Towards a history-friendly model. Industrial and Corporate Change 11:667-703

Mayer C, Pence K, Sherlund S (2009) The rise in mortgage defaults. Journal of Economic Perspectives 23:27-50

McLean B, and Nocera J (2011) All the devils are here: The hidden history of the financial crisis. Penguin Group, New York

Mildenberg D (2008) Bank of America to acquire Countrywide for $\$ 4$ billion http://www.bloomberg.com/apps/news?pid=newsarchive\&sid=aqKE9kRcKDEw, Accessed 3 November 2014

Minsky, H (1992) The financial instability hypothesis, Jerome Levy Economics Institute of Bard College, working paper 74

Muolo P, Padilla M (2010) Chain of Blame: How Wall Street caused the mortgage and credit crisis. John Wiley and Sons, Hoboken, New Jersey

Nelson R (1995) Recent evolutionary theorizing about economic change, Journal of Economic Literature 33: $48-90$

Oman M (2010) Fcic.law.stanford.edu/resource/interviews. Accessed 14 July 2014

Purnanandam A (2011) Originate-to-distribute model and the subprime mortgage crisis. The Review of Financial Studies 24:1881-1915

Sambol D (2010) fcic.law.stanford.edu/resource/interviews. Accessed 14 July 2014

San Pedro F (2010) fcic.law.stanford.edu/resource/interviews. Accessed 14 July 2014

Stumpf, J (2010) fcic.law.stanford.edu/resource/interviews. Accessed 14 July 2014

Sanders A (2008) The subprime crisis and its role in the financial crisis. Journal of Housing Economics 17: 254-261

Securities and Exchange Commission (2010) Former countrywide CEO Angelo Mozilo to pay SEC's largest-ever financial penalty against a public company's senior executive http://www.sec.gov/news/press/2010/2010-197.htm, Accessed 3 November 2014

Securities and Exchange Commission (2009) Securities and Exchange Commission vs. Angelo Mozilo, David Sambol, and Eric Sieracki, United States District Court, Central District of California

Sengupta R (2010) Alt-A: The forgotten segment of the mortgage market. Federal Reserve Bank of St. Louis Review 92: 55-71

Sengupta R, Noeth B (2011) Changes in the mortgage market since the crisis. Economic Synopses 26:1-2

Sung T, Carlsson B (2003) The evolution of a technological system: the case of CNC machine tools in Korea. Journal of Evolutionary Economics 13: 435-460

Teal D (2003) Option ARM Focus Groups - phase I: WAMU loan consultants and mortgage brokers. http://www.hsgac.senate.gov//imo/media/doc/Financial_Crisis/041310Exhibits.pdf?. Accessed 10 December 2015.

Teal D, Baker C (2003) Option ARM focus groups - phase II: WAMU option ARM customers. 
http://www.hsgac.senate.gov//imo/media/doc/Financial_Crisis/041310Exhibits.pdf?. Accessed 10 December 2015.

The Economist (2015, May 9) From the people, for the people; Peer-to-peer lending. The Economist, 6 


\section{Figures and Tables}

Figure 1. Shift in the structure of mortgage financing - one new equilibrium

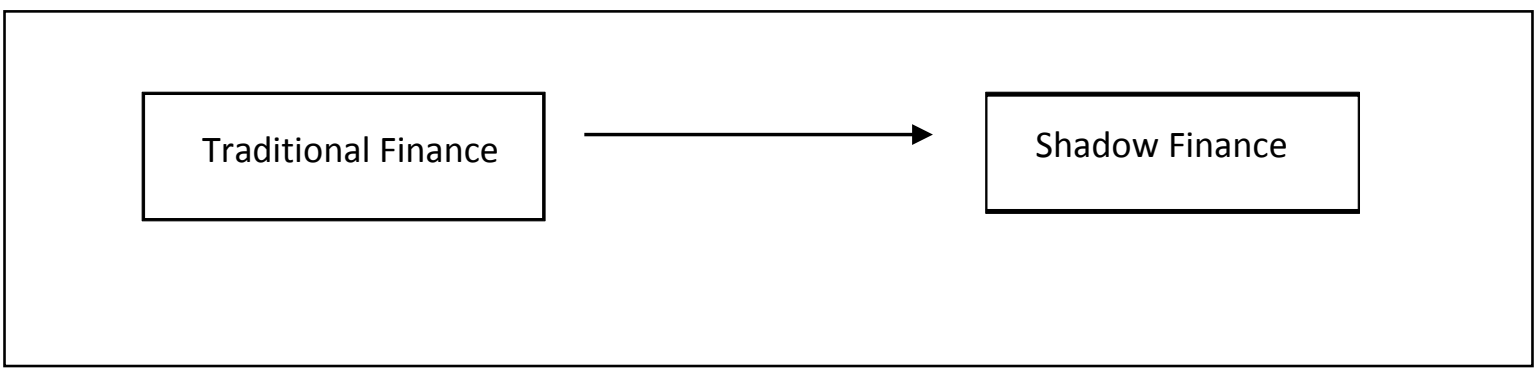

Figure 2. Shift in structure of mortgage banking - two possible new equilibria.

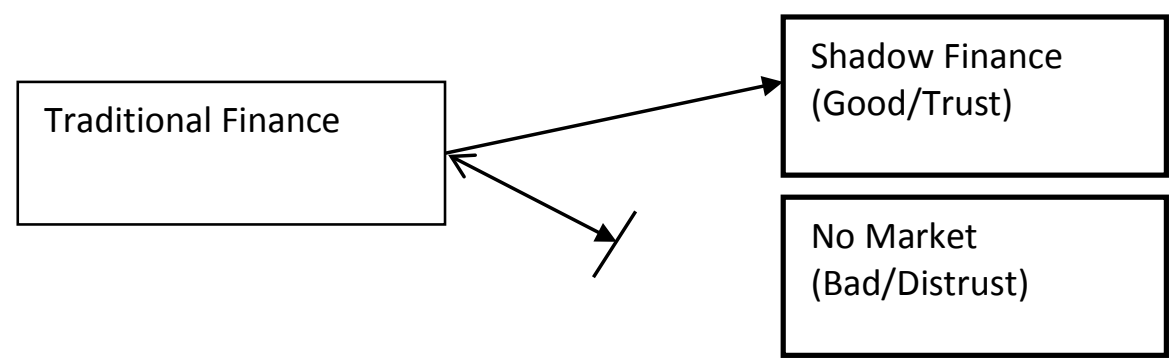


Figure 3. Shift in structure of mortgage banking - Multiple States

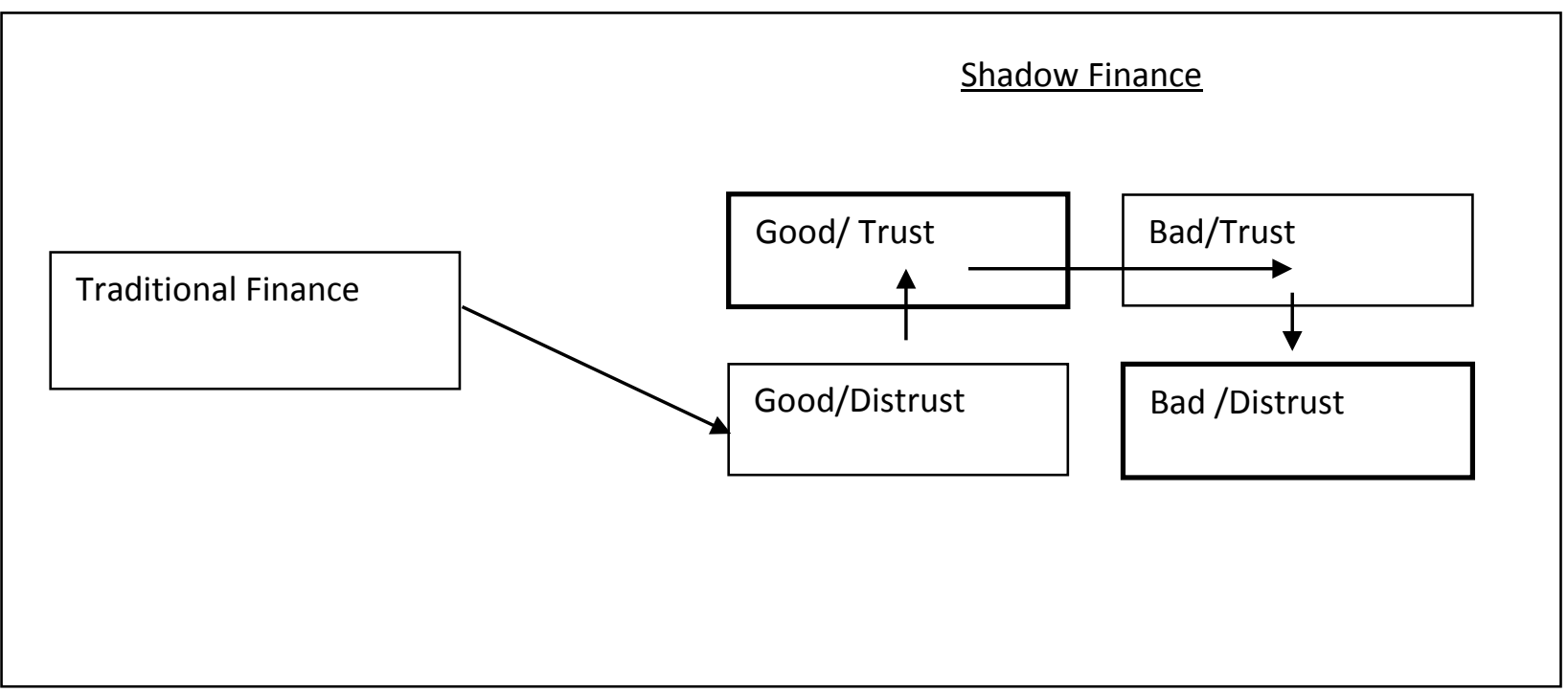

Table 1. Originations of Pay-Option ARMs in 2006 by top 10 mortgage originators and other significant ARM originators.

\begin{tabular}{llll}
\hline Company & $\begin{array}{l}\text { Total } \\
\text { Originations }\end{array}$ & $\begin{array}{l}\text { Pay-Option } \\
\text { Originations }\end{array}$ & Outcome after financial crisis \\
\hline Countrywide Financial & 463 & 70 & Failed, purchased by Bank of America \\
Wells Fargo & 398 & 0 & \\
Washington Mutual & 196 & 41 & Failed, purchased by JPMorgan Chase \\
CitiMortgage & 183 & 0 & \\
Chase Home Finance & 173 & 0 & \\
Bank of America & 168 & 2 & Failed, purchased by Wells Fargo \\
Wachovia (Golden West) & 105 & 31 & \\
Residential Capital Group & 97 & 11 & Filed for bankruptcy \\
Indy Mac & 90 & 21 & Failed, bankruptcy \\
GMAC Residential Holding & 75 & 0 & Subsidiary of Bear Stearns, failed, \\
& & 23 & Furchased by JPMorgan Chase \\
EMC Mortage $^{\text {a }}$ & & 19 & Subsidiary of Capital One, closed \\
American Home Mortgage $^{\text {a }}$ & & 13 & \\
Green Point Mortgage $^{\mathrm{a}}$ & & & \\
\end{tabular}

${ }^{\mathrm{a}}$ These firms originated over $\$ 10$ billion of pay-option ARMs, but were not top 10 originators. Subprime originations not available.

Source: Inside Mortgage Finance Publications, Inc. Copyright 2008 